\title{
Coopetition-based business models: The case of Amazon.com
}

\author{
Paavo Ritala ${ }^{\mathrm{a}, *}$, Arash Golnam ${ }^{\mathrm{b}, 1}$, Alain Wegmann ${ }^{\mathrm{b}, 1}$ \\ a School of Business, Lappeenranta University of Technology, PO Box 20, FI-53851 Lappeenranta, Finland \\ ${ }^{\mathrm{b}}$ Ecole Polytechnique Fédérale de Lausanne, School of Computer and Communication Sciences (IE'C), Systemic Modeling Laboratory (LAMS), Station 14, CH-1015 Lausanne, Switzerland
}

\section{A R T I C L E I N F O}

\section{Article history:}

Received 29 February 2012

Received in revised form 30 September 2013

Accepted 13 November 2013

Available online 5 December 2013

\section{Keywords:}

Coopetition

Collaboration

Competition

Business Model

Amazon.com

Case study

\begin{abstract}
A B S T R A C T
Coopetition (collaboration between competing firms) is a phenomenon that has recently captured a great deal of attention due to its increasing relevance to business practice. However, current research on coopetition is still short on explaining how the potential advantages of coopetition can be realized over time as part of an individual firm's business model. In order to gain insights into this, we conduct a longitudinal, in-depth case study on the coopetition-based business models of Amazon.com. We find evidence of three distinct coopetition-based business models: (1) Amazon Marketplace, (2) Amazon Services and Web Services, and (3) the collaboration between Apple and Amazon on digital text platforms. We conclude by forwarding several propositions on how value can be created and captured by involving competitors in a firm's business model. As a whole, the results contribute to the current understanding of how firms - as well as their stakeholders - can better benefit from coopetition.
\end{abstract}

(c) 2013 Elsevier Inc. All rights reserved.

\section{Introduction}

Firms increasingly collaborate with their competitors to gain benefits that they could not achieve alone, including risk and cost sharing, sharing distribution channels, co-marketing, and collaborative innovation. In academic research, as well as in business practice, this phenomenon has been named coopetition (see e.g. Bengtsson \& Kock, 2000; Brandenburger \& Nalebuff, 1996). Coopetition typically evolves over time and shapes the competitiveness of firms, as well as the overall logic of industries (Andersen \& Fjelstad, 2003; Choi, Garcia, \& Friedrich, 2010; Roy \& Yami, 2009; Rusko, 2011; Wang \& Xie, 2011). Firms that are successful in their coopetition strategies and activities are thus well positioned to gain competitive advantages over other industry actors in various contexts. For instance, both Sony and Samsung have been shown to reap major benefits from applying coopetitive elements in their strategy in LCD-TV markets (Gnyawali \& Park, 2011). A study by Kock, Nisuls, and Söderqvist (2010) illustrates that coopetition strategies have been beneficial for internationalizing small and medium-sized firms in Finland. Furthermore, a recent study (Peng, Pike, Yang, \& Roos, 2012) shows how a focal firm in the Taiwanese supermarket network has been able to utilize coopetition over time to increase its performance.

The above examples show that coopetition can be a beneficial strategy for firms and that there are many ways and contexts in which such coopetition-related advantages can be achieved. However, the existing

\footnotetext{
* Corresponding author. Tel.: +358408335852.

E-mail addresses: ritala@lut.fi (P. Ritala), arash.golnam@epfl.ch (A. Golnam), alain.wegmann@epfl.ch (A.Wegmann).

1 Tel.: +41216934381.
}

strategic and marketing literature has not examined this issue systematically from a perspective that would explicitly distinguish between different types of coopetition-related advantages and the mechanisms leading to such advantages. In this article, we suggest that using a business model perspective is helpful in understanding how an individual organization can affect the mechanisms of value creation and capture in a coopetition context. Thus, we approach the aforementioned research gap by introducing the concept of coopetition-based business models. While there are many definitions of a business model, most of them include either the explicit or implicit notion that business models should include the logic for value creation and capture. In fact, a business model has been generally defined as a platform between strategy and practice, describing the value creation and capture mechanisms at a firm's disposal (e.g. Amit \& Zott, 2001; Chesbrough \& Rosenbloom, 2002; Teece, 2010). There is thus a clear linkage between business models and coopetition, since value creation and capture are at the heart of both seminal (Brandenburger \& Nalebuff, 1996) and more recent conceptualizations of how coopetition relationships could be analyzed (Gnyawali \& Park, 2009; Ritala \& Hurmelinna-Laukkanen, 2009).

In our formulation of coopetition-based business models, we take into account not only the perspective of the focal firm but also the whole coopetition logic in terms of simultaneously collaborating and competing actors related to a particular business model. In particular, we answer the question of how a particular firm can increase value creation by involving competitors in its business model, and what the mechanisms are through which the firm itself can capture value in such settings.

To provide evidence in this setting, we present a longitudinal, singlecase study examining Amazon.com's coopetition-based business models since the firm's establishment. As a concept, the business model initially gained ground in e-business, since it was able to capture 
the industry's complex and varied nature (e.g. Amit \& Zott, 2001; Shin \& Park, 2009; Timmers, 1998). The empirical part of this study is also in this context, and thus we believe that the business model concept will be especially helpful for our analysis. In particular, the analysis is conducted on Amazon.com's coopetition in the global book industry. We have used data triangulation to incorporate rich evidence on the case: The sources include annual reports and financial statements, news releases, interviews, as well as existing research evidence (e.g., Harvard Business School cases, journal articles, books) on Amazon.com. The results of our study show that Amazon.com has successfully adopted coopetition-based business models in three particular phases over time - all of which have had a substantial impact on the global book industry, as well as on Amazon.com's survival, growth, and evolution.

The results contribute theoretically to the coopetition literature by integrating the business model perspective with the analysis of coopetition strategies of individual firms. This also adds to the existing business model conceptualizations, which do not usually explicitly include competitors within the business model of the firm. Empirically, we analyze how coopetition-based business models are utilized and combine these insights with theoretical development, resulting in propositions on the role of coopetition-based business models in value creation and capture. These results help to analyze the impact of individual firms' coopetition strategies from a systematic perspective and differentiate between value creation and capture, which has been called for in earlier coopetition research (Gnyawali \& Park, 2009; Ritala \& Hurmelinna-Laukkanen, 2009).

The remainder of this study is formulated as follows. First, we discuss the key concepts of the study. Second, we develop a theoretical background for the generic drivers of coopetition-based business models and provide concrete examples from the existing literature. This is followed by a longitudinal case study of Amazon.com's evolution in terms of coopetition initiatives. Next, we put forward a set of propositions on the rationale of involving competitors within the business model of a firm. Finally, we present our conclusions and suggestions for further research.

\section{Coopetition and business models}

Coopetition has been broadly defined as collaboration between competing firms or the simultaneous competition and collaboration between the same actors (Bengtsson \& Kock, 2000). In this paper, we discuss coopetition as a simultaneously collaborative and competitive relationship, which takes place between two or more firms within the same value chain position, that is, between horizontal actors. The second key concept for this study is business model. In terms of the level of analysis, the business model can be seen as a structural template that takes into account the focal firm's transactions with its external constituents (Zott \& Amit, 2008). This makes the concept especially suitable for the purpose of examining the rationale of coopetition. In fact, we follow the recent suggestions by Mason and Spring (2011) in analyzing the business model not only from the focal firm perspective but also as a larger construct incorporating the collaboration architecture of the firm.

More specifically, the business model has been defined as a generic platform between strategy and practice, describing the design or architecture of the value creation, delivery, and capture mechanisms the firm employs (e.g. Teece, 2010), as well as the changes in these processes over time (Amit \& Zott, 2010). Therefore, the seminal view of coopetition as a means to create a larger business pie (value) together and simultaneously competes in dividing it up (Brandenburger \& Nalebuff, 1996) fits neatly with the chosen business model perspective. In fact, the strategic logic of coopetition has been recently discussed as involving collaborative activities that jointly create value and firmspecific activities in capturing, dividing, and appropriating that value (e.g., Gnyawali \& Park, 2009; Ritala \& Hurmelinna-Laukkanen, 2009). Thus, for analytical purposes we focus on two facets in coopetition- based business models: value creation and value capture. In terms of the former, we focus on processes through which value is created and delivered to the customers through a coopetition-based business model, and in terms of the latter, we discuss processes that lead to the eventual capturing of value and profit-taking from the part of an actor utilizing a coopetition-based business model.

Even though coopetition may sometimes develop in the form of emergent strategies (Mariani, 2007; Padula \& Dagnino, 2007), we suggest that it is useful to build a suitable business model in order to fully reap the benefits of coopetition. This is because coopetition relationships are typically hard to manage (e.g. Tidström, 2009) but, when successful, involve potential for major rewards in terms of increased innovativeness or profitability (Hamel, 1991; Quintana-García \& Benavides-Velasco, 2004; Walley, 2007). To employ the coopetition strategy in practice, we suggest that it is useful to have a coopetitionbased business model where certain competitors are positioned as collaborative partners. This type of business model describes how coopetition-related plans are executed to create customer value and how the firm is able to capture a portion of the profits generated by that value. In the following section, we discuss four generic drivers for coopetition-based business models and examine how these models can facilitate the creation and capture of value.

\section{Generic drivers of coopetition-based business models}

The mechanisms explaining how inter-firm relationships and networks help to create and capture value can be intuitively explained with resource-based arguments (see e.g. Dyer \& Singh, 1998; Lavie, 2006). In general, through inter-firm relationships, firms integrate both supplementary and complementary resources in an attempt to create more value than if they were used separately (e.g. Das \& Teng, 2000). Furthermore, the role of both relational and firm-specific resources essentially determines how much value can be created and who is in the position to appropriate it (Dyer, Singh, \& Kale, 2008; Lavie, 2006). The value created in inter-firm relationships and networks can be linked to explorative issues such as innovation, market expansion, and differentiation, or more exploitative issues such as cost reduction, through joint production and distribution (Möller \& Rajala, 2007).

In the coopetition context, the resource-based logic has certain specific characteristics that should be discussed here. In particular, it has been suggested that through joint resource utilization, firms in coopetition can collaboratively create value, while they capture or appropriate a portion of that value by utilizing their firm-specific resources (Ritala \& Hurmelinna-Laukkanen, 2009). Even though this is the case in any inter-firm relationship, in coopetition this issue is pronounced because the competitive positioning between the firms suggests that value capture takes place (at least potentially) in the same domain. In addition, the division between relational and firm-specific resources may not be clear-cut in coopetition. This is because the role of resources used to create value in coopetition is paradoxical, as the same resources can often be used for both competition and collaboration (Bengtsson \& Kock, 2000); conflicts may thus emerge (e.g. Hamel, 1991; Tidström, 2009). Therefore, a coopetition-specific business model, which takes these issues into account, would be useful in avoiding conflicts over value capture and, at the same time, maximizes joint value creation through the utilization of shared supplementary and complementary resources.

The suitable coopetition-based business model naturally depends on the goals and motivations behind coopetition, and therefore there is no one "basic model" in this context. Indeed, earlier research has identified several different motives and drivers for coopetition strategy in different levels of analysis (see e.g. Gnyawali \& Park, 2009, 2011; Ritala, 2012). Building on these sources, as well as on the resource-based rationale outlined above, we divide the generic drivers of coopetition-based business models into four broad types: (1) increasing the size of the current markets, (2) creating new markets, (3) efficiency in resource 
utilization, and (4) improving the firms' competitive position. The categories are not mutually exclusive, but they are presented here separately for analytical purposes.

\subsection{Increasing the size of the current markets}

The first and most often cited driver of coopetition is increasing the market. Coopetition can act as a means of increasing the size of the participating firms' current markets and, in that way, grow the "size of the pie," so there is more to divide among all (Brandenburger \& Nalebuff, 1996). The basic relationship between competitors is often that of a "zero-sum game," whereas the motivation behind market-sizeincreasing coopetition is to collaborate in finding ways to create a "positive-sum game" (Ritala, 2009). As the competing firms operate in the same domain, collaboration to increase the value created in that domain can provide win-win situations for all the competitors involved. Therefore, the competing firms are likely to have common interests in increasing the size of the current markets.

Two specific rationales can be identified behind the market-sizeincreasing business models in coopetition. First, even though competitors operate in the same domain and therefore provide more or less similar types of offerings to (at least partially) the same customers, they are still likely to use different, unique resources and capabilities in seeking benefits from coopetition (Bengtsson \& Kock, 2000). Thus, it can be suggested that coopetition is an innate driver for firms to leverage their resource complementarities in market expansion efforts. For instance, one firm may have very strong marketing capabilities, whereas the other is strong in manufacturing and design. By combining these resources, the competing firms are able to build a more lucrative business model, which may enlarge the market potential for both firms. In particular, the utilization of complementarities may even be more effective in coopetition than in other relationship types, since the competing firms possess increased "relative absorptive capacity" between them due to ex ante similarity in knowledge domains and business logic (Dussauge, Garrette, \& Mitchell, 2000; Lane \& Lubatkin, 1998; Ritala \& Hurmelinna-Laukkanen, 2009). Second, collaboration between competitors is also often formed for the purpose of bundling sufficient quantities of similar, supplementary resources, in addition to solely building on synergies created through different or complementary resources (Garrette, Castañer, \& Dussauge, 2009, see also Das \& Teng, 2000). In fact, the competing firms, by their nature, have a high degree of resource similarity between them (e.g. Chen, 1996); therefore, there are opportunities to utilize such resources to better enable efforts to increase the size of the current markets. As this type of pursuit is always a risky and resource-intensive task, there should be major benefits in combining supplementary resources (e.g., financial assets, manufacturing, and logistics capabilities).

The well-documented coopetition between Sony and Samsung (see e.g. Gnyawali \& Park, 2011) is a good example in which both of the above-mentioned resource-based rationales are in use. By establishing joint technology development and manufacturing facilities in South Korea, the two firms were able to overtake market leadership in the LCD TV markets during the last decade. The superior technological knowhow of Sony and the marketing abilities and insights of Samsung can be seen as complementary resources that created a very competitive alliance between the two. At the same time, the firms were able to share the costs and risks by establishing joint facilities (and thus combining supplementary resources). The relationship has not been without tension, since Sony and Samsung compete head-to-head in the LCD TV markets, and they represent traditional rivals between neighboring countries (Japan and South Korea). However, as an outcome of the alliance, the LCD TV markets have grown worldwide, and Sony and Samsung have become central actors in this field. Another example are the alliances between car manufacturers in technology and platform sharing (see e.g. Gwynne, 2009; Segrestin, 2005). In these cases, the firms share resources to develop and leverage technologies, simultaneously competing head-to-head over customers through differentiation and branding. This does not happen only within multibrand consortiums such as Volkswagen but also between actual competitors such as Peugeot, Citroën, and Toyota.

\subsection{Creating new markets}

Coopetition-based business models also sometimes aim for the creation of completely new markets. This is understandable, since in this way the competing firms may create completely new value over which to compete, providing new possibilities for value capture for each firm involved. There are four main explanations for new market creation as a driver of coopetition-based business models.

First, as competitors operate in similar domains, they also possess insights that can help in creating radical innovations and recognizing new markets in which to expand their offerings (Quintana-García \& Benavides-Velasco, 2004; Ritala \& Hurmelinna-Laukkanen, 2009). In particular, knowledge similarity possessed by competitors on current markets, as well as on the possibilities in the business environment, may help the firms to exploit their complementary resources even more strongly to create new offerings in new markets.

Second, especially in high-growth sectors (such as the ICT sector), an individual firm cannot capture all the potential value created through new business models. In such contexts, having a large base of competing offerings (differentiated through firm-specific resources) in the markets often helps the firms to create competitive and appealing end markets from the customer point of view. In fact, Wang and Xie (2011) recently found that consumer product valuation is positively affected by the extent to which competitors have adopted the same solution. A broad repertoire of various smart phone manufacturers, for example, helps to serve different customer segments better and increase product and service awareness, compared to the situation in which only one provider would be available.

Third, coopetition can be beneficial to the creation of industries and offerings where positive network externalities, compatibility, and interoperability play a role (Mione, 2009; Ritala, Hurmelinna-Laukkanen, \& Blomqvist, 2009; Spiegel, 2005; Wang \& Xie, 2011). Network externalities are related to offerings where the value the user receives from a product or service depends on the number of other users utilizing the same or a similar offering (Katz \& Shapiro, 1985). A classic example of network externalities is the mobile phone and the GSM standard. Without seamlessly operating networks (hosted by competing firms), the end customers could not reach each other. By enabling such interoperability, the GSM system facilitated the creation of the markets of mobile communication at an extremely rapid pace. In such contexts, the competing firms are in key roles to form a common basis for utilizing resources that work together in a way that provides interoperability and, in the end, positive network externalities (see also Wang \& Xie, 2011). In particular, a certain amount of resource similarity/supplementarity (i.e., market and technological knowledge, language, business logic) possessed by competitors enables them to form offerings enabling positive network externalities (see e.g. Ritala et al., 2009).

Finally, risk and cost sharing is an important motivation for collaborating with competitors in market creation (e.g. Gnyawali \& Park, 2009). Radical innovations and offerings often involve major costs and a lot of uncertainty; therefore, collaboration between horizontally positioned firms helps in pursuing such goals, since they can bundle the needed supplementary resources together to tackle such market uncertainty (e.g. Möller \& Rajala, 2007; Perry, Sengupta, \& Krapfel, 2004).

A well-documented example of coopetitive market creation is the socalled AIM alliance (Apple, IBM, \& Motorola), which focused on designing and manufacturing a new generation of microprocessors with reduced instruction set computer (RISC) architecture (see e.g. Duntemann \& Pronk, 1994; Vanhaverbeke \& Noordehaven, 2001). In the early 1990s, Apple, IBM, and Motorola came to an agreement to establish an alliance to develop the PowerPC (Performance Optimized with Enhanced RISC 
Processor Chip). Apple was to adopt a single-chip implementation of IBM's RS/6000 (multi-chip processor), to be designed and manufactured by AIM, in their Macintosh personal computers. In addition, IBM and Apple intended to create a new open-system software platform and operating system that would be based on object-oriented technology. During the time the alliance was established, Apple and IBM were direct competitors in the personal computer market. The collaboration in the AIM alliance had the potential to create new value outside the current markets and to create new value capture opportunities for both firms with the introduction of a new type of computer microprocessor architecture.

In terms of exploiting supplementary resources, coopetition-based business models harnessing network externalities and ensuring interoperability are typical in contemporary industries, such as the ICT industry (Amit \& Zott, 2001). An example of this is the standards war between Blu-Ray and HD-DVD (see e.g. Christ \& Slowak, 2009). In the end, the Blu-Ray consortium (involving competitors), led by Sony, eventually won the race for the dominant high-definition video standard. Coopetition played a major role in this by ensuring interoperability between the incumbent electronics manufacturers, as well as by sharing the risks and bundling sufficient resources involved in pursuing the de facto standard. However, it should be kept in mind that some of the firms in the Blu-Ray consortium did not fare as well as others, since the eventual value capture depends on firm-level activities. Ritala et al. (2009) document another example of coopetitive market creation where interoperability and similar resources were utilized. In this case, the collaborative development of technologies and services behind mobile TV in Finland involved competing telecom operators and media companies that together pursued market creation (Ritala et al., 2009). In this case, the collaboration did help to create common technologies and commercial pilots, but there were challenges when moving towards the actual value capture phase with individual, diversified business models.

\subsection{Efficiency in resource utilization}

While both of the aforementioned drivers of coopetition involve sharing risks and costs as part of their rationale, there are also coopetition-related business models focusing solely on cost reduction and quality assurance within existing activities. This is a different logic in that it seeks to make existing value creation and capture mechanisms more efficient, i.e., to produce more with the same resources or to utilize fewer resources in producing the same output. In fact, it has been widely suggested that the collaboration part of coopetition relationships often takes place far from the customer, in operations that are linked to manufacturing, logistics, and other functions that can benefit from scale advantages (see, e.g., Bengtsson \& Kock, 2000; Walley, 2007). Indeed, it has been suggested that these "scale alliances" enable the competing firms to bundle similar/supplementary resources in their efforts to gain efficiency benefits and cost sharing (Dussauge et al., 2000). Competitors are, by definition, conducting similar types of activities in similar positions in the industry value chain; therefore, there should be plenty of possibilities to collaborate on resource efficiency related issues.

Based on the above, we suggest that business models related to efficiency in resource utilization are connected to the exploitation of supplementary resources and capabilities situated in the same part of the value chain. For instance, Swedish breweries collaborate to return empty beer bottles from the wholesalers (Bengtsson \& Kock, 2000). The rationale here is that the distance and transport methods are similar, and thus efficiency benefits from such collaboration are notable. It is also important to notice here that collaboration in this area leaves plenty of space for competition in other areas close to the customer, such as distribution and branding. Other well known examples of resource efficiency and coopetition include the airline alliances (Oum, Park, Kim, \& $\mathrm{Yu}, 2004)$. In these cases, the alliances are formed around brands such as "Star Alliance" or "OneWorld," and they are used to save costs in marketing, ticketing, and logistics related to the airline business.

\subsection{Improving the firms' competitive position}

In general, the rise of alliances and other networked governance forms have shifted the locus of competition towards network-againstnetwork competition (Gomes-Casseres, 1994; Gueguen, 2009). For instance, a common strategy in the ICT field is to compete with rival networks in pursuit of increasing the competitiveness of a certain coopetitive ecosystem (Gueguen, 2009). Lado, Boyd, and Hanlon (1997) argue that the most potentially beneficial strategy for a firm may be connected to so-called syncretic rent seeking behavior, which combines both collaboration and competition so that firms collaborate with some competitors while competing even more intensively with others. In terms of coopetition, affecting the competitive dynamics of the industry is a separate driver of its own, as firms often seek to increase their own competitive position, as well as the competitive position of the whole collaborative network, through coopetition. According to Möller and Rajala (2007), the role of horizontal actors in the overall network is pronounced if they have products, channel relationships, or customer service systems that, in combination, help them to achieve an even stronger position in global competition. Thus, by combining their supplementary and complementary resources, competitors within one coopetition-based business model or network can make their position even more competitive against the rest. Several empirical studies support this logic. First, the results of Gnyawali, He, and Madhavan (2006) suggest that centrally positioned firms in coopetitive networks will act in a more versatile manner in terms of their competitive actions. This is a reflection of superior resource access and thus increased bargaining power. Second, the results of Oxley, Sampson, \& Silverman, (2009) suggest that coopetition can increase the competitiveness of firms participating at the expense of other industry actors. Based on this discussion, we suggest that this category of coopetitionbased business models can improve the relative value held by the resources of the firm and its competitors by co-opting other rival offerings, firms, and networks.

This type of competitiveness enhancing motivation was apparent in the business model used by the participants of the AIM (Apple, IBM, \& Motorola) alliance to produce microprocessors that could tackle the dominance of the Microsoft and Intel ecosystem, known as Wintel (see e.g. Duntemann \& Pronk, 1994; Vanhaverbeke \& Noordehaven, 2001). The motivation for collaboration between rivals Apple and IBM was the goal of increasing their competitiveness against Microsoft and Intel, which were dominating the markets at the time. Several illustrative industry-level examples have also been mentioned in previous research. First, in their case study, Choi et al. (2010) show how Australian and New Zealand wine producers collaborated in introducing screw cap type bottles in order to make the whole industry more competitive against intense global competition. However, the producers simultaneously pursued the capture of their own share of the market by utilizing their firm-specific resources and differentiated brands. Similarly, Rusko (2011) describes how the Finnish forestry industry relied on coopetition, especially in its development phase, to increase its competitiveness in the global market. The early years of collaboration focused on upstream activities, followed by mid-stream activities. Now, the industry has matured and, by the introduction of EU legislation, the coopetition initiatives have ended. Overall, Rusko (2011) suggests that coopetition had a notable effect on the growth of competitiveness and sustainability of the Finnish forestry sector.

In sum, we have thus far forwarded four generic drivers for coopetition-based business models enabling market expansion, market creation, resource efficiency, and competitive benefits by involving collaboration with competitive firms in business models in various ways. Table 1 summarizes the discussion so far. 
Table 1

Coopetition-based business models.

\begin{tabular}{|c|c|c|c|c|}
\hline $\begin{array}{l}\text { Business } \\
\text { model } \\
\text { emphasis }\end{array}$ & $\begin{array}{l}\text { Resource-based drivers for } \\
\text { coopetition }\end{array}$ & $\begin{array}{l}\text { Coopetition-related business model } \\
\text { specifics in value creation }\end{array}$ & $\begin{array}{l}\text { Coopetition-related business model } \\
\text { specifics in value capture }\end{array}$ & Illustrative case examples \\
\hline $\begin{array}{l}\text { Increasing the } \\
\text { size of the } \\
\text { current } \\
\text { markets }\end{array}$ & $\begin{array}{l}\text { Expanding the size of the current } \\
\text { markets through leveraging on the } \\
\text { synergies between competitors' } \\
\text { complementary resources and } \\
\text { sharing market expansion costs } \\
\text { through supplementary resources }\end{array}$ & $\begin{array}{l}\text { Value can be created by utilizing the } \\
\text { competitive position between firms to } \\
\text { identify and pursue opportunities for } \\
\text { market expansion }\end{array}$ & $\begin{array}{l}\text { Value can be captured in a positive, } \\
\text { rather than zero-sum, fashion when } \\
\text { markets are expanding }\end{array}$ & $\begin{array}{l}\text { The rise of Sony and Samsung as the } \\
\text { market leaders in LCD TVs by com- } \\
\text { bining the unique capabilities of } \\
\text { both and the utilization of joint } \\
\text { facilities for cost sharing purposes } \\
\text { (Gnyawali \& Park, 2011) } \\
\text { Collaboration between car manu- } \\
\text { facturers to share and develop plat- } \\
\text { forms and technologies, over which } \\
\text { to build individually-branded prod- } \\
\text { ucts (Gwynne, 2009; Segrestin, } \\
\text { 2005) }\end{array}$ \\
\hline $\begin{array}{l}\text { Creating new } \\
\text { markets }\end{array}$ & $\begin{array}{l}\text { Creating new markets through } \\
\text { finding new places for value creation } \\
\text { with the help of differentiated, } \\
\text { complementary resources of } \\
\text { competitors, and decreasing market } \\
\text { uncertainty through the utilization of } \\
\text { shared, supplementary resources }\end{array}$ & $\begin{array}{l}\text { Value can be created by utilizing the } \\
\text { competitive position between firms to } \\
\text { identify new market creation } \\
\text { opportunities and ensure the creation of } \\
\text { new markets by providing broad-based, } \\
\text { unified platforms and offerings to cus- } \\
\text { tomers }\end{array}$ & $\begin{array}{l}\text { In new markets, all value that has been } \\
\text { created represents new value capture } \\
\text { potential for the participating firms; the } \\
\text { eventual value captured depends on the } \\
\text { firm-specific business model and even- } \\
\text { tual differentiation }\end{array}$ & $\begin{array}{l}\text { Collaboration among Apple, IBM, \& } \\
\text { Motorola to produce new, RISC- } \\
\text { based microprocessors (Duntemann } \\
\text { \& Pronk, 1994; Vanhaverbeke \& } \\
\text { Noordehaven, 2001) } \\
\text { Coopetition for gathering resources } \\
\text { behind Blu-Ray technology to en- } \\
\text { sure the creation of a de facto stan- } \\
\text { dard for new technology (Christ \& } \\
\text { Slowak, 2009) } \\
\text { Coopetition for ensuring interopera- } \\
\text { bility and development of new } \\
\text { services for mobile TV in Finland } \\
\text { (Ritala et al., 2009) }\end{array}$ \\
\hline $\begin{array}{l}\text { Efficiency in } \\
\text { resource } \\
\text { utilization }\end{array}$ & $\begin{array}{l}\text { Increasing the efficiency of a certain } \\
\text { part of the value chain through joint } \\
\text { utilization of complementary and } \\
\text { supplementary resources and } \\
\text { capabilities }\end{array}$ & $\begin{array}{l}\text { Since they are situated in the same } \\
\text { phase of the value chain, competitors } \\
\text { can create value by sharing and } \\
\text { combining resources to increase the } \\
\text { efficiency of their basic or standardized } \\
\text { activities and leveraging their } \\
\text { differentiated resources elsewhere }\end{array}$ & $\begin{array}{l}\text { Fewer resources are needed to realize a } \\
\text { certain amount of value capture, or } \\
\text { more value can be captured by using the } \\
\text { same resources }\end{array}$ & $\begin{array}{l}\text { Collaboration among Swedish brew- } \\
\text { eries concerning the returning of } \\
\text { bottles from wholesalers (Bengtsson } \\
\text { \& Kock, 2000) } \\
\text { Collaboration in the global airline } \\
\text { industry in the form of airline alli- } \\
\text { ances that share costs related to } \\
\text { marketing, logistics, and ticketing } \\
\text { (Oum et al., 2004) }\end{array}$ \\
\hline $\begin{array}{l}\text { Improving the } \\
\text { firms' } \\
\text { competitive } \\
\text { position }\end{array}$ & $\begin{array}{l}\text { Improving the relative value of } \\
\text { resources held by the firm and its } \\
\text { competitors by co-opting other rival } \\
\text { offerings, firms, and networks }\end{array}$ & $\begin{array}{l}\text { Value is created by finding } \\
\text { opportunities to differentiate the } \\
\text { offerings of firms utilizing the } \\
\text { coopetition-based business model }\end{array}$ & $\begin{array}{l}\text { Value capture possibilities are increased } \\
\text { in relation to the firms outside the } \\
\text { domain of the business model }\end{array}$ & $\begin{array}{l}\text { The Apple, IBM, and Motorola alli- } \\
\text { ance as a means to control Intel and } \\
\text { Microsoft dominance (Duntemann } \\
\text { \& Pronk, 1994; Vanhaverbeke \& } \\
\text { Noordehaven, 2001) } \\
\text { - Coopetition tradition as a means of } \\
\text { ensuring the long-term sustainabil- } \\
\text { ity and competiveness of the Finn- } \\
\text { ish forestry industry (Rusko, 2011) } \\
\text { Coopetition among Australian wine } \\
\text { producers to increase the competi- } \\
\text { tiveness of the continent in global } \\
\text { competition (Choi et al., 2010) }\end{array}$ \\
\hline
\end{tabular}

\section{Methodology and data collection}

We conducted a longitudinal, qualitative single-case study (Yin, 2003), which is a valuable method for the purposes of holistically analyzing previously unexplored phenomena (e.g. Eisenhardt, 1989) and also suitable for studying business network-related issues (Halinen \& Törnroos, 2005). In particular, we utilize Amazon.com as a descriptive case study to explain a phenomenon and the real-life context in which it occurred (Baxter \& Jack, 2008; Yin, 2003). The case study approach was chosen because the research field on coopetition is still sparse; there is even less evidence available about coopetition-based business models. Furthermore, we chose Amazon.com as the case company due to its special focus on various coopetition-based business models. Throughout the case study, we concentrate especially on the book segment of Amazon.com's business to enable a detailed exploration of coopetition-based business models within a certain industrial domain.

To conduct the empirical study, we adopted an approach similar to Rusko (2011) in utilizing a broad repertoire of secondary data to gain an in-depth view of the coopetitive business models. The data gathering by the researchers took place between 2009 and 2013. The main body of data consists of a variety of secondary data sources, which have been accessed, analyzed, and synthesized in order to gain an accurate understanding of the diverse facets of the Amazon.com business model and, in particular, the firm's coopetitive relationships with other firms over time. The main data sources include: 1) Amazon.com annual reports from 1997-2012, 2) Amazon investor relation presentations, 3) news releases, 4) books published on Amazon.com, written by industry or Amazon.com insiders (e.g., Brandt, 2011; Kalpanik \& Zheng, 2011; Spector, 2002), 5) Harvard Business School cases (e.g., Anand, Olson, \& Tripsas, 2009; Applegate, 2002, 2008; Collura \& Applegate, 2000), 6) interviews with Amazon.com CEO Jeff Bezos (e.g., Ignatius, 2013; Kirby \& Stewart, 2007; Levy, 2011; Rose \& Bezos, 2011), and (7) journal articles (e.g., van Heck \& Vervest, 2007).

While the usage of primary sources in particular has generally been seen as beneficial in obtaining in-depth evidence, there are several advantages to using secondary sources as well, even as the main source of data. For instance, Ambrosini, Bowman, and Collier (2010) recently suggested that teaching cases are an unexploited and rich source of data that should be used when primary data is not available. They also suggested that the reliability of such data is improved when researchers 
use reputable sources of teaching cases and combine them with other sources to attain data triangulation. In our data gathering, we sought to do just this to form a rich picture of the coopetitive business models throughout the history of Amazon.com. Amazon.com is a firm that has exceptionally large public interest, and, therefore, there is a large amount of secondary data available. To ensure the quality of the secondary data used here, we mainly rely on more or less direct interview data on Amazon.com insiders (mostly the CEO, Jeff Bezos); we also use Harvard business school cases, as well as official and subjective reports written by Amazon.com insiders or industry experts. In addition, we provide many illustrative direct quotes in order to make the analysis more transparent. It should be acknowledged that the secondary data also has limitations that should be taken into account here. These limitations include the difficulty of assessing the reliability of the data, as well as a lack of relevant data access (e.g., Saunders, Lewis, \& Thornhill, 2009). We intend to tackle (at least some of) these limitations through the actions outlined above.

In addition to the secondary sources, primary data was also gathered to increase and validate the researchers' understanding of Amazon.com's coopetition-based business models through data triangulation (e.g. Creswell \& Miller, 2000). Two semi-structured interviews were conducted with a person in charge of one of Amazon.com's international websites. The interviews were conducted in 2010 and 2013, and the themes of the first interview were Amazon Marketplace, infrastructure, and web services in general, while the second interview covered questions on the researcher's perceptions of the three coopetition-based business models of Amazon.com, as well as the assessment of the role of coopetition in Amazon.com's business model in the future. The insights gained from these interviews were used to complement the secondary data sources, especially in assisting the researchers in interpreting the Amazon.com business models from a coopetition perspective.

\section{Case study: Amazon.com}

Amazon.com is currently the leading e-commerce firm in the world. To achieve this, it has used unique business models, which provide interesting evidence on how value is created and captured effectively while collaborating with competitors. While most of the dot com companies typically operate on the basis of straightforward business models with pre-specified revenue streams, Amazon.com has continued to evolve its business model, pushing the boundaries of what could be accomplished on the internet (Brandt, 2011; Collura \& Applegate, 2000). In particular, it can be suggested that a major part of the evolution of Amazon.com's business model rests heavily upon the firm's coopetitive strategies; in this study, we focus especially on the coopetition-based business models introduced by Amazon.com over time. In the following section, we first briefly review the history.

\subsection{Short history and the business model evolution of Amazon.com}

In July 1995, Amazon.com began as an online bookseller; by September 1995 , the company was selling $\$ 20,000$ per week. After nearly three years as an online bookseller, the company began aggressively diversifying its offerings to include other product categories beyond books, initially adding music, videos, toys, and electronics. These diversifications were followed by the launch of several other stores, such as home improvement and software. In parallel with such product diversifications, in October 1998, Amazon.com expanded geographically by launching its first international sites, Amazon.co.uk and Amazon.de through the acquisition of the UK-based online bookstore book pages and the German-owned Telebook. The rationale behind this was Amazon.com's strategy of "get big fast," to turn Amazon into the biggest mass merchandiser in the online world (Brandt, 2011; Kalpanik, 2011; Spector, 2002).

The "get big fast" strategy was combined with an overall business model that prioritizes the customer. The Annual Report of Amazon.com in 1997 specified that growth was the main goal, over profitability, within the business model and that it could be achieved by focusing on customers in the long term (Amazon.com Investor Relations, 2011). In the Annual Report of 1998, the company's mission was already defined to be "the most customer-centric organization in the world" (Amazon.com Investor Relations, 2011). This focus remains even today. The Amazon.com website states that the company's mission is "to be Earth's most customer-centric company where people can find and discover anything they want to buy online" (Amazon.com Investor Relations, 2013). This statement has been followed through upon by product and service introductions that have expanded from initial book sales on the web to sales of any possible item online, including the delivery of online content and services through Kindle devices and tablet computers.

\subsection{The role of coopetition in the overall business model of Amazon.com}

Throughout its existence, Amazon.com has become known as an extremely customer-oriented company, even at the expense of not following or reacting to competitors. Amazon.com CEO Jeff Bezos has commented on this by saying: "We don't ignore competitors; we try to stay alert to what they are doing, and certainly there are things that we benchmark very carefully. But a lot of our energy and drive as a company, as a culture, comes from trying to build these customer focused strategies. And actually I do think they work better in fast-changing environments" (Kirby \& Stewart, 2007, 59). In fact, the customer centricity of Amazon.com's overall business model and strategy has been shown in its unique approach to competitors. In particular, coopetition has been a major part of Amazon.com's business model, since the company sees it as a way to create even more customer value than is otherwise possible. While such value creation potential is the basis in all coopetition initiatives (e.g. Brandenburger \& Nalebuff, 1996), Amazon.com has been especially explicit from early on in its understanding of how competitors can also be collaborative partners in the quest for increased customer value.

The first clue of Amazon.com's coopetitive orientation is the company's recognition that the online commerce market can fit many competing firms in many roles and that there is also room for collaboration in these growing markets. The early signs of this mindset are visible in the 1997 Letter to Shareholders, which states that “...online bookselling, and online commerce in general, should prove to be a very large market, and it's likely that a number of companies will see significant benefit" (Amazon.com Investor Relations, 2011). This was, again, recently recognized explicitly by Jeff Bezos: "There is room for many winners here" (The Economist, 2012).

The second major issue driving Amazon.com's coopetitive initiatives is the recognition that the processes, infrastructure, and brand of Amazon.com are more valuable to the customers when they are utilized as broadly as possible, including through the use of competitors. The early signs of this focus are also mentioned in the 1997 letter to shareholders, where the long-term investment goal was recognized "to expand and leverage our customer base, brand and infrastructure as we move to establish an enduring franchise" (Amazon.com Investor Relations, 2011). At that point, the utilization of these resources was not yet fully recognized as a platform for coopetition-based business models, but later on, this issue became much more explicit when Amazon.com started actively sharing its infrastructure with the competitors. This was commented upon by Jeff Bezos: "The common question that gets asked in business is, why? That's a good question, but an equally valid question is, why not? This is a good idea, we have a lot of skills and assets to do this well, we're already going to do it for ourselves - why not sell it, too?" (Levy, 2011). Furthermore, on the same issue, Amazon.com manager (authors' interview) said: "If you want to be a platform, you have to sign up as many of the market players as possible - even if that means branding for competitors (who then become customers). Otherwise you can never become the predominant player." 
As the above-mentioned discussion and quotes show, Amazon.com has been oriented towards customer value creation and has identified that coopetition can be a major part of this goal. These approaches and philosophies related to coopetition as part of customer value creation have been put into practice in several of the coopetition-based business models in the company's history (and present). Furthermore, the role of coopetition can be seen as an emergent part of Amazon.com's strategy, as it has been gradually included within its business model over time. Amazon.com's overall strategic perspective is as long as seven years (see Ignatius, 2013), and this means that successful business models realize profit or die out over a long - rather than short - time span. For this reason, the specific business models involving coopetition can be seen as partly emergent, yet initially recognized as part of the overall strategy.

In the timeline in Fig. 1, we summarize Amazon.com's coopetitive business models within the broader development of the company. These fall into three basic groups. First, the launch of Amazon Marketplace, where competitors of any size can leverage Amazon.com's ecommerce platform and customer base by placing their items alongside Amazon.com's offerings. Second, the Borders website is powered by Amazon.com's e-commerce platform through Amazon Services; Amazon Web Services also provides infrastructure for their fierce content rival, Netflix. Lastly, Amazon.com has pursued coopetitive benefits in making the Kindle app available on Apple's iPad. This application allows iPad owners to read e-books in Amazon.com's proprietary e-book format AZW, while Amazon.com's Kindle e-reading devices (including the recent Kindle Fire) compete with Apple's iPad.

In the following sections, we go deeper into Amazon.com's coopetition-based business models and discuss how they have affected the possibilities of value creation and capture for both Amazon.com and its coopetition partners.

\subsection{Amazon Marketplace}

Following its evolution from an online bookseller to a consumer shopping portal by diversifying its product offerings through new store openings, Amazon.com extended its business model to include a thirdparty marketplace by launching Amazon Marketplace in November 2000. As illustrated in the timeline in Fig. 2, this idea was then implemented in Amazon.com's international websites, UK and Germany in 2002 and France, Canada, and Japan in 2003. In the following section, we examine the contribution of coopetition to the implementation of this strategy, as well as to Amazon.com's value creation and capture.

Amazon Marketplace was the first instance of Amazon.com's coopetition-based business models. Basically, it enables sellers to draw on the e-commerce services and tools to present their product alongside Amazon.com on the same product detail page on the website, hence pursuing what Jeff Bezos phrased as "the single store strategy." In other words, a single page provides the customer with a choice between purchasing a new product from Amazon.com or a new or used product from another seller (i.e., Amazon.com's competitor) on the Amazon Marketplace (Kalpanik, 2011; Kalpanik \& Zheng, 2011). According to an Amazon.com manager, the Marketplace “...demonstrated a leap in our business model - a transformation from a retailer to a true Marketplace," because "merchants were able to offer their items right next to Amazon's, right there side by side on the same page" (Kalpanik \& Zheng, 2011). To illustrate this business model from the customer perspective, Fig. 2 depicts the product information interface on the Amazon Marketplace as viewed by a customer who intends to buy a book.

As can be seen, the product information page lists Amazon's price, as well as the lowest price from other booksellers for a new book and a used copy. More information about the vendors, such as their ratings, shipping rates, and return policies, is provided on the supplier information page, as shown in Fig. 3.

Amazon Marketplace is, in effect, the epitome of a coopetition-based business model. In terms of collaboration, Amazon.com provided thirdparty sellers with automated tools to migrate their catalogs of millions of new, used, and out-of-print books onto the new product pages within the Amazon.com books tab. This created the opportunity for them to merchandise their products on the highly trafficked web pages that historically had sold only Amazon.com's products. Amazon.com even went further by providing a feature that allowed individual book buyers to list a single book item for sale on the Amazon.com product page (see Fig. 3, the bottom section).

While collaborating with the bookstores by providing them with the infrastructure and technical means to market and sell their products

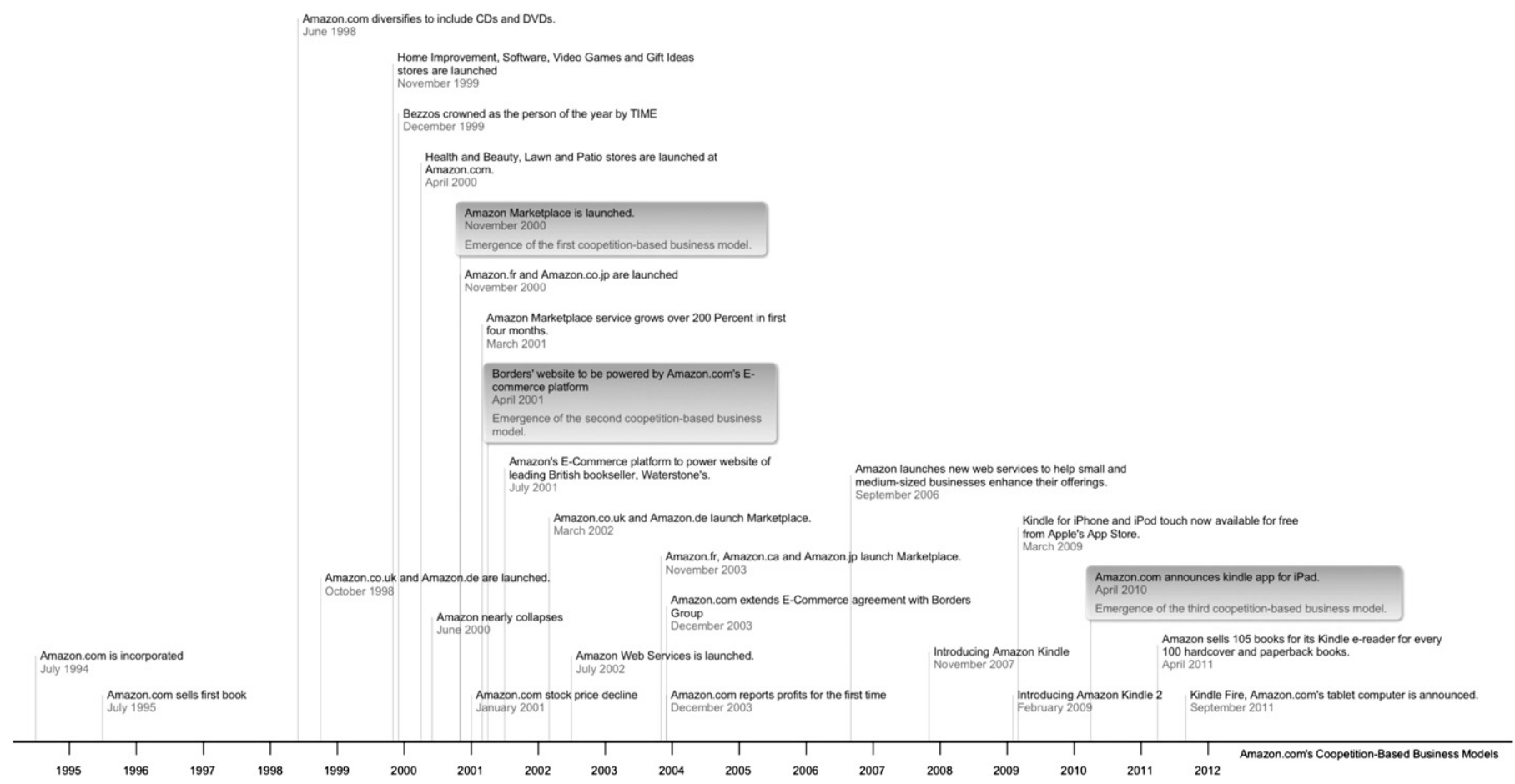

Fig. 1. Amazon.com timeline (source: Amazon.com news releases). 


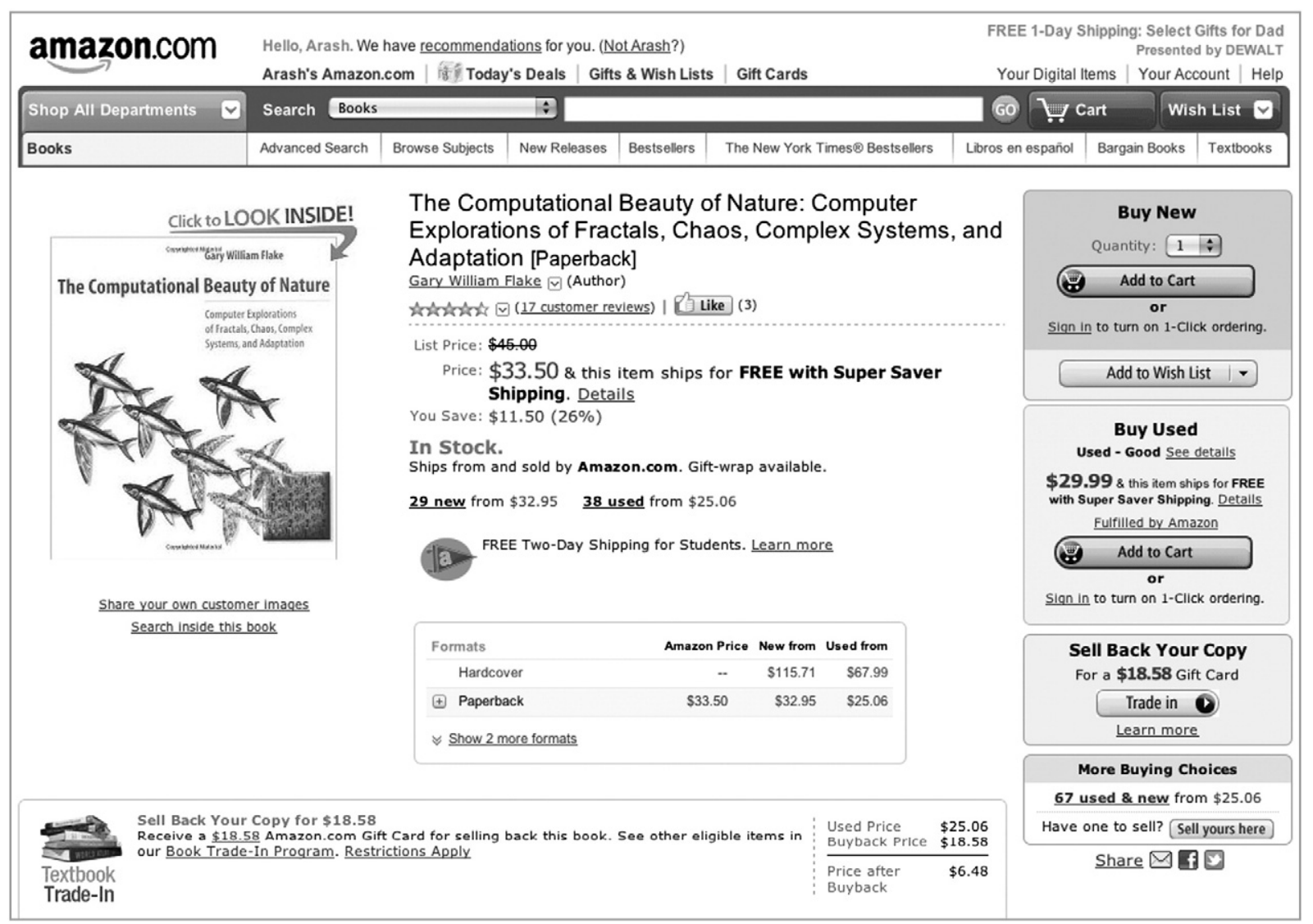

Fig. 2. Amazon marketplace product information interface.

online, Amazon.com and the booksellers on the Marketplace are in a head-to-head price competition to win customer orders. In the 2005 Annual Report, Bezos expresses his opinion about Amazon.com's coopetition-based business model with Amazon Marketplace in the following way:

“....in 2000 we invited third parties to compete directly against us on our 'prime retail real estate' - our product detail pages. Launching a single detail page for both Amazon retail and third-party items seemed risky. Well-meaning people internally and externally worried it would cannibalize Amazon's retail business, and - as is often the case with consumer-focused innovations - there was no way to prove in advance that it would work. Our buyers pointed out that inviting third parties onto Amazon.com would make inventory forecasting more difficult and that we could get "stuck" with excess inventory if we "lost the detail page" to one of our third-party sellers. However, our judgment was simple. If a third party could offer a better price or better availability on a particular item, then we wanted our customer to get easy access to that offer. Over time, third party sales have become a successful and significant part of our business. Third-party units have grown from 6\% of total units sold in 2000 to $28 \%$ in 2005 , even as retail revenues have grown three-fold."

In fact, there was a lot of internal and external doubt and resistance about including third-party sellers within Amazon.com's own webstore. First, according to Kalpanik and Zheng (2011), the introduction of Amazon Maketplace “....was initially a cause of concern since many people felt that third party sellers would sell their products at prices lower than the price we were selling the same product for, thus cutting into our sales." Some vendors also advised Amazon not to offer third-party products on their front page and let the customer decide which price was the most attractive. The decision to let customers write reviews of the books on the company's web page was also frowned upon by some. The company admitted that many of these "odd" decisions reduced their profits, but their effects should not be assessed in the short run. These actions were part of their strategy to focus on serving the customer. Although the company has taken these bold steps, some of the risks paid off and helped Amazon cope with the turbulent environment. (Amazon.com, Letter to Shareholders, 2001-2003). Furthermore, in 2007, Bezos admitted that, at the time, the decision to implement Amazon Marketplace was controversial and not at all an easy decision, as it [Marketplace] gets the seller customer but loses you the buyer customer (Kirby \& Stewart, 2007, 77). In addition, he said that "we talked a lot about that [Marketplace] before we did it. But when the intellectual conversation gets too hard because of these potential cannibalization issues, we take a simple minded approach...Well, what's better for the consumer?" (Kirby \& Stewart, 2007, 79). Thus, it can be said that Amazon Marketplace - as a coopetition-based business model - was situated within the overall customer-oriented approach of Amazon.com, and this is why it was eventually implemented.

Despite the criticism and debate, Amazon Marketplace was eventually deemed a success. Before its establishment, by the summer of 2000 , Amazon's stock price had dropped by more than two-thirds and, by the end of 2000 , was down more than $80 \%$ from the beginning of 2000 , leading to speculation about bankruptcy or acquisition (see e.g. Applegate, 2002, 2008; Brandt, 2011). It can be suggested that Amazon Marketplace was part of the solution that helped to achieve eventual profitability at Amazon.com, since it helped to offset operating expenses and increase sales (other activities to increase profitability included laying off workers, closing warehouses, improving logistics, and cutting down unprofitable products; see Frey \& Cook, 2004). First, it lowered operating expenses because there was less need to store products. The incremental cost of each sale for Amazon.com was close to zero, with very low incremental variable fulfillment costs associated with the 


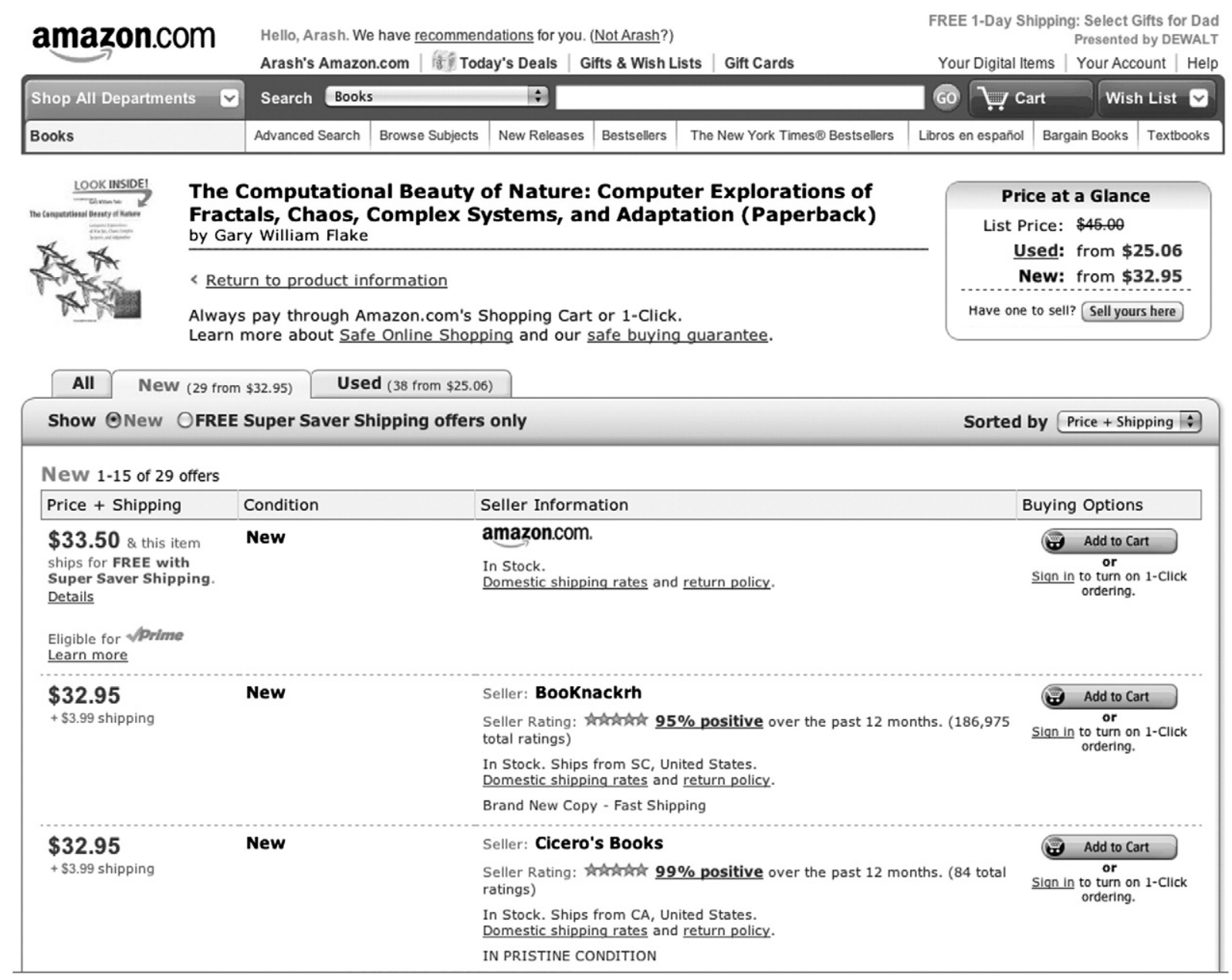

Fig. 3. Amazon marketplace seller information interface.

sale for Amazon.com (Chiles \& Dau, 2005). Thus, the company was able to gain brokerage fees at negligible additional cost. Second, in terms of revenues, an Amazon.com manager was recently quoted as saying: "The combination of commissions and subscriptions ensured we will make pretty good money independent of whether customer bought the product from us (Amazon) or from a 3rd party merchant; and we made money either way by charging commissions and subscription fee" (Kalpanik \& Zheng, 2011). As early as in the second quarter of 2002, Amazon reported that third-party transactions accounted for $20 \%$ of its North American units sold. In 2010, Amazon Marketplace accounted for over 35\% of Amazon.com's sales (Brandt, 2011).

This type of coopetition-based business model is not only beneficial to Amazon.com. In fact, it has been particularly beneficial to small bookstores: Prior to their online presence on Amazon Marketplace, they were having a tough time competing with Amazon.com and the book superstores, such as Barnes \& Noble and Borders. The period from 1993-1996 marks the launch of Amazon.com and the opening of over 450 Barnes \& Noble book superstores and 348 Borders. During the same period, over 200 independent bookstores went out of business (Brandt, 2011). Amazon Marketplace gave these booksellers the opportunity to present their offerings to millions of potential customers.

\subsection{Amazon Services and Amazon Web Services}

April 2001 marks the emergence of Amazon.com's second coopetition-based business model, related to its transition to an ecommerce service provider. This business model started initially when
Amazon.com made an agreement with Borders, one of its toughest brick and mortar competitors, to launch and power Borders' online operations on Borders.com. Based on the agreement, Amazon.com provided Borders with an e-commerce solution of technology services, including inventory, fulfillment, site content, and customer service, in order to help Borders establish online operations. The agreement between Amazon.com and Borders was, in fact, part of a broader business perspective. Amazon.com had realized that, in time, the traditional retailers would begin to realize how difficult it is to succeed on the internet. With such insights, Amazon.com had perceived the creation of a whole new market as retailers became more interested in outsourcing their online presence. Thus, it began to build resources and capabilities to collaborate with companies, so that Amazon.com would be responsible for significant portions of their online operations under the brands Amazon Services and Amazon Web Services. Bezos has recently commented on this logic as follows: "Then we realized, whoa, everybody who wants to build web-scale applications is going to need this. We figured with a little bit of extra work we could make it available to everybody. We're going to make it anyway - let's sell it" (Levy, 2011).

In addition to Amazon Marketplace, this type of coopetition-based business model can be seen as a natural continuation to the firm's customer value creating approach to coopetition. In a recent interview (Levy, 2011), Bezos points to the controversies surrounding the decision to provide e-commerce services to competing companies and explains Amazon.com's vision of becoming "Earth's most customer-centric company" stressing that, unlike most companies, Amazon focuses on its customers rather than its competitors. 
In 2003, the official launch of the subsidiary Amazon Services, established to help other retailers improve their online presence, was announced. Amazon Services offers a variety of e-commerce services that allow retailers to set pricing and other transaction conditions, manage and coordinate the logistical processes for the transfer of the physical or digital goods, assure the quality of the goods sold, verify the credibility of buyers and sellers, settle payments, and arrange funds transfers (van Heck \& Vervest, 2007). As Amazon.com had expected, other companies followed Borders and started adopting Amazon.com e-commerce services (including Waterstone's, the UK's leading specialist bookseller, Target Corporation, the second largest retailing company in the US, Marks \& Spencer, the leading United Kingdom retailer, and Sears Canada, Canada's most popular retail website). By working with Amazon Services, such merchants could power their e-commerce offerings from end-to-end, including technology services, merchandising, customer service, and order fulfillment.

As a parallel development, Amazon.com introduced Amazon Web Services (AWS) in July 2002. By launching AWS, Amazon.com distinguished itself as a web service provider in terms of cloud computing and data storage, which followed the same coopetition-based business model logic of Amazon Services but provided even larger infrastructure and resource sharing. In a recent interview (Levy, 2011), Bezos recognized this issue explicitly: "Over the past eight years, the company has capitalized on its data center expertise to build a vast cloud computing platform, which hosts web operations for some of the world's largest Internet companies - even competitors like Netflix." In fact, the coopetitive relationship between Netflix and Amazon.com vividly illustrates the logic of this business model. While Amazon.com is making storage and web operations cheaper for Netflix, it is making its operations harder elsewhere through tough competition on the streaming video content front (for discussion, see Dignan, 2012). The business model embedded in AWS makes it possible for Amazon.com and Netflix to both participate in value creation by providing cost-effective content over the AWS infrastructure, even though they at the same time compete to capture value on the customer end.

\subsection{Amazon Kindle and the digital text platform}

In November 2007, Amazon introduced Kindle, its e-reading device, to the market. Kindle displays books that are in Amazon.com's proprietary e-book format "AZW." In February 2009, Amazon.com introduced an enhanced model of Kindle to the market, known as the Kindle 2. On May 20th, 2011 it was announced that Kindle books outsold print books on Amazon.com. Amazon announced that, since April 2011, it has sold 105 books for its Kindle e-reader for every 100 hardcover and paperback books sold, including books without Kindle versions and excluding free e-books. It is intriguing to know that the Amazon.com print book business dates back 15 years, whereas Amazon.com has only been in its Kindle book business for fewer than four years. It is estimated that three out of every four books sold are in Kindle format (Brandt, 2011). Thus, e-book growth is an integral part of Amazon.com's "get big fast" strategy; in this case, the coopetition-based business model was introduced after the expansion had started.

Apple, a major rival, challenged Amazon.com by releasing the iPad in April 2010 as an e-reader device/tablet with an iBooks application that was developed for reading e-book contents in E-PUB format. E-PUB has also been adopted by several other companies in the e-reader market, such as Sony. Soon after the launch of the iPad, Amazon.com and Apple began coopetition: Apple is distributing Amazon.com's e-book content through the Kindle app on the iPad platform (see e.g., Kalpanik \& Zheng, 2011). Prior to this, the Kindle app was made available by Amazon.com on Apple's iPod touch and iPhone, where Apple iBooks were already available. In January 2010, Amazon.com announced that authors and publishers around the world could then use the self-service Kindle Digital Text Platform (DTP) to create content in the Kindle format, upload, and sell books in English, German, and French to customers worldwide in the Kindle Store. Capitalizing on its coopetitive relationship with Apple, Amazon.com managed to increase the sales of books in AZW format and establish AZW as one of the standard formats in the e-publishing market, right next to E-PUB (Anand et al., 2009). This also led to the increasing popularity of Amazon.com's AZW format among authors who could develop their content for this platform and self-publish their books.

In September 2011, Amazon.com introduced a new family of Kindle devices, including the Kindle Fire, Amazon.com's tablet computer. The launch of Kindle Fire in November 2011 made the coopetitive relationship between Apple and Amazon.com even more apparent. In 2010, when the Kindle application was released for the Apple iPad, Amazon.com's Kindle device was considered merely an e-reader, whereas Apple's iPad was a more expensive tablet computer with countless other features. However, the two companies were already in competition in the e-reader market. In early 2011, Kindle had an estimated $47 \%$ of the market share, while Apple's iPad had a $32 \%$ share. Other actors, such as the Sony Reader and Barnes \& Noble Nook lagged behind with $5 \%$ and $4 \%$ of the market share, respectively. The launch of the Kindle Fire put Amazon.com and Apple in a head-to-head competition in the tablet computer market. Marketing experts in the computer industry suggest that the Kindle Fire is to be the fiercest rival for Apple's iPad (Levy, 2011).

This development can be recognized as the third instance of Amazon.com's coopetitive business, and it relies on sharing resources and content among competitors to create larger customer value than otherwise possible. Amazon.com gets a broader distribution for its Kindle and DTP content, which in turn increases the attractiveness of Apple's iPad as a content providing platform. Thus, both firms create and capture value together in the domain of iPad content providing, while they simultaneously compete with the Kindle Fire and iPad platforms. The overall Kindle business model for Amazon.com is based on content, and the device is more a complementary resource. In a recent interview, Bezos remarked upon this approach (Ignatius, 2013): "Well, our approach to our hardware Kindle devices, Kindle Fire and our Kindle readers, is to sell the hardware at near break even, and then we have an ongoing relationship with the customer where they buy content from us digital books, music, movies, TV shows, games, apps." This approach illustrates the rationale of the coopetition-based business model, as it is all about the content, and much less about the medium over which the content is delivered. Thus, the medium of a direct competitor (Apple's iPad) is one way to create value for the customer.

Table 2 summarizes all of Amazon.com's coopetition-based business models discussed in this section.

\section{Analysis of Amazon.com's coopetition-based business models}

Overall, with the help of the aforementioned coopetition-based business models, Amazon.com has evolved, in approximately 15 years, from an online retailer to one of the world's leading ecosystems in media and web services. The longitudinal case presented in this study suggests that coopetition can shape the individual business models of the central actors and that the coopetitive interactions taking place can provide value for the industry participants in a way that would not be available through the separate utilization of competitive and collaborative strategies.

In the following section, we formulate distinct propositions based on the insights of the case study and the earlier outlined theoretical categorization of the four generic drivers of coopetition-based business models (see Table 1). In particular, we take into account the coopetition motivations and drivers of not only the focal firm, but also other actors, to understand how coopetition-based business models may optimally work. Our aim is to link back to the business model's architectural purpose of value creation and capture (e.g. Amit \& Zott, 2010; Teece, 2010) and thus formulate propositions that answer our research questions on how a particular firm can increase value creation by involving 
Table 2

Summary of Amazon.com's coopetition-related business models.

\begin{tabular}{|c|c|c|c|}
\hline & Amazon Marketplace & Amazon Services and Amazon Web Services & Amazon Kindle \\
\hline Coopetition logic & $\begin{array}{l}\text { Offerings increased the variety of new, used, and } \\
\text { out-of-print books in the Amazon.com web store }\end{array}$ & $\begin{array}{l}\text { Sharing the Amazon.com web store platform and } \\
\text { infrastructure with competing actors }\end{array}$ & $\begin{array}{l}\text { Distribution of electronic book content across } \\
\text { different, competing platforms }\end{array}$ \\
\hline $\begin{array}{l}\text { Amazon's main } \\
\text { coopetitive } \\
\text { partners }\end{array}$ & $\begin{array}{l}\text { Independent, third-party bookstores and book } \\
\text { sellers }\end{array}$ & $\begin{array}{l}\text { Borders, Target (utilizing Amazon's web store } \\
\text { platform), Netflix (utilizing Amazon's web } \\
\text { infrastructure) }\end{array}$ & $\begin{array}{l}\text { Apple (Amazon.com's content on the iPad through } \\
\text { the Kindle app) }\end{array}$ \\
\hline $\begin{array}{l}\text { Value for } \\
\text { Amazon.com }\end{array}$ & $\begin{array}{l}\text { More valuable and varied end customer offerings; } \\
\text { margin of the competitors' profits }\end{array}$ & $\begin{array}{l}\text { Profits for running the service; broader utilization and } \\
\text { development possibilities for the web store platform }\end{array}$ & $\begin{array}{l}\text { Access to a broader customer base; profits from } \\
\text { content sales; an increased user base for the DTP } \\
\text { standard }\end{array}$ \\
\hline $\begin{array}{l}\text { Value for } \\
\text { Amazon.com's } \\
\text { competitors }\end{array}$ & Access to a broader customer base; increased sales & $\begin{array}{l}\text { Establishing an online presence; highly reliable e- } \\
\text { commerce service }\end{array}$ & $\begin{array}{l}\text { Increase of the attractiveness of the iPad as an } \\
\text { e-reader due to increased content }\end{array}$ \\
\hline $\begin{array}{l}\text { Potential issues/ } \\
\text { problems }\end{array}$ & $\begin{array}{l}\text { Cannibalization of Amazon.com's own sales, } \\
\text { internal and external resistance }\end{array}$ & $\begin{array}{l}\text { Helping to boost/create competition; cannibalization } \\
\text { of Amazon.com's own sales }\end{array}$ & Reduction in the sales of the Kindle devices \\
\hline
\end{tabular}

competitors in its business model, and what the mechanisms are through which the firm itself can capture value in such settings.

\subsection{Letting your competitors win}

A seminal game theoretic rationale by Brandenburger and Nalebuff (1996) is that "letting your competitors win too is ok, as long as you win yourself." Later on, this has been extended in a discussion suggesting that when markets grow, coopetition is especially lucrative because it allows a "positive-sum game" between actors in coopetition (see Ritala \& Hurmelinna-Laukkanen, 2009). On the basis of the case study, this has resonated in the success of the first coopetition-based business model of Amazon.com, in which competitors were able to create value for their customers through the Amazon Marketplace. This type of approach has increased the size of the whole market for electronic book sales worldwide. In this case, the competing firms were able to explore wider markets by complementing each others' resources and capabilities (e.g., Amazon providing the platform, customer base, and infrastructure, and the third-party bookstores providing improved variety and broader availability). The Kindle app for the iPad is a similar case, in which the content in Amazon.com's proprietary format has been made available for Apple's customers, and thus the market base has been broadened through complementary offerings.

Both of the above-mentioned business models show that it can be beneficial to let the competitors increase their markets as part of the firm's business model. We suggest that the benefit for a focal firm comes from the possibility of the firm capturing a portion of the added value that has been created (an integral part of any business model, see e.g., Teece, 2010). In addition, customers tend to appreciate more options to choose from. As customer value is increased when there are a variety of competing offerings in a similar domain (Wang \& Xie, 2011), by consciously sharing its platforms to competitors, Amazon.com could enhance such value. Based on these discussions, we put forward the following proposition:

Proposition 1. Increasing the size of the competitors' markets by involving them as part of the firm's business model provides added potential for the firm to capture a portion of the increased customer value.

The same intuition also applies to completely different markets that were created for Amazon.com's rivals, as seen in the case of Amazon Services. By delivering a platform for Borders, Amazon.com was able to capture a portion of the unique value associated with the brand, the customer base loyal to Borders. In fact, there are certainly some customer segments that wanted to be associated with Borders, rather than Amazon.com; through coopetition, both types of customers could be satisfied (supporting the findings of Wang \& Xie, 2011). Furthermore, although such customer segments are somewhat out of Amazon.com's reach, the value created by Borders can be partially captured by
Amazon.com through the business model of Amazon Services. The same argumentation certainly holds for the recent relationship with Netflix, and potentially even more strongly: By collaborating with Netflix, Amazon.com is able to capture some of the value created by the lucrative content portfolio Netflix has to offer.

In both of these instances, it can be recognized that the creation of a new market for competitors requires a critical amount of shared resources within the coopetition-based business model (here, the Amazon.com infrastructure). By utilizing this joint resource base, the firms could create value that would not otherwise be available and engage in competition on the customer end (as suggested by Ritala et al., 2009; Ritala \& Hurmelinna-Laukkanen, 2009). Furthermore, as suggested by Lavie (2006) and Dyer et al. (2008), the relative share of value capture potential is higher for actors that share more valuable resources to enable value creation in the first place. Thus, the design of the coopetition-based business model, in a way that created new markets for competitors, allowed Amazon to capture their own - otherwise nonexistent - share. This discussion allows us to formulate the following proposition:

Proposition 2. Creating new markets for competitors by involving them as part of the firm's business model provides added potential for the firm to capture a portion of the newly created customer value.

\subsection{Sharing costs and risks with competitors to gain resource efficiency}

Amazon.com had sunk huge investments and resources into developing its web-based platforms and infrastructure. By transforming the platform to suit the needs of its competitors in the form of Amazon Services and Amazon Web Services, Amazon.com was able to realize notable resource efficiency benefits. Because Amazon.com shared the platform, it was not only them but also others that could benefit from exploiting the already sunk costs and resources.

There are many reasons why sharing resources with competitors for efficiency purposes may be lucrative. The overall ratio of benefits versus costs will improve within the business model when resources are shared with competitors in activities for which they have joint interests and that are usually far away from the customer end (Bengtsson \& Kock, 2000; Dussauge et al., 2000). This leads to a wider impact for existing resources; thus, fewer resources are needed to create and capture a larger amount of value than otherwise would have been captured. In fact, when competitors create value together by sharing their resources, they are well placed to individually compete for the created value through differentiated offerings. This has been illustrated in the Amazon.com case through numerous coopetitive relationships where the joint infrastructure has enabled competitors to spread their offerings to markets. In summary, in certain situations, it is valuable for the focal firm to enlarge the group of actors exploiting its resources, even 
when it helps its competitors. Based on this discussion, the following proposition can be put forward:

Proposition 3. Involving competitors in the firm's business model helps it gain resource efficiency benefits through increased application and synergy of resources, thus increasing firm's value capture potential.

\subsection{Increasing competitiveness}

In the global marketplace, some firms operate through utilizing Amazon.com's platforms and some through other platforms, representing network or ecosystem-level competition (Gomes-Casseres, 1994; Gueguen, 2009). Thus, competitiveness against other (groups of) competitors increased in the case of Amazon Marketplace and Amazon Services, since certain segments within the global book markets can be defined in terms of competitive groups going head-to-head with each other. The same intuition goes for the Kindle: By enabling Amazon.com to offer content through the Kindle app, the competitive positions of both Apple and Amazon.com are increased against other book market industry competitors. Thus, the firms were able to utilize coopetition to bundle their supplementary and complementary resources together into a more competitive overall business model. In particular, this can increase their competitiveness against other rivals outside the scope of the business model (see, e.g., Lado et al., 1997, on syncretic rent seeking behavior). Taking into account the aforementioned evidence, we suggest that, in certain conditions, it is beneficial to improve the market potential of the firm's competitors, especially when this improves the competitive positioning of the focal firm as well. The following proposition summarizes this discussion:

Proposition 4. Involving competitors in the firm's business model provides a potential for an improved resource and competitive positioning against other business models in the industry, and thus increasing the firm's value capture potential.

\section{Conclusion}

In this study, we have focused on the ways in which the potential advantages of coopetition (collaboration between competitors) can be realized by involving competitors in the firm's business model. To examine this issue, we conducted an in-depth case study of Amazon.com's coopetition-based business models throughout its history. The results provide evidence of how Amazon.com has utilized such business models in three particular phases since the year 2000. This has led to market growth, resource efficiency, and increased competitiveness not only for Amazon.com but also for its coopetitive network of thirdparty sellers, content providers, and large multi-national competitors. Based on this case study, we created propositions about the benefits for a firm to formulate coopetition-based business models. These models include involving competitors in the firm's business model, thus creating market potential and competitiveness for those competitors. These types of suggestions are quite counterintuitive when assessed through the lens of the traditional competitive paradigm. In terms of coopetition, this type of paradoxical approach is needed (see, e.g., Clarke-Hill, Li, \& Davies, 2003; Peng et al., 2012), as is the shift towards "non-traditional" competitive strategies and business models (Sharma, 2002). Based on the case study, we show that such non-traditional strategies and business models can be used to provide potential for positive-sum results for each actor involved, which is a requirement for crafting successful coopetition relationships in general (Brandenburger \& Nalebuff, 1996; Lado et al., 1997; Ritala \& Hurmelinna-Laukkanen, 2009).

\subsection{Theoretical implications}

The main contribution of this study is to show distinct aspects inherent in a firm's business models that can help to create and capture value by including coopetition relationships. In doing this, we have taken into account the larger network environment in which the firm is embedded, the supplementary and complementary resources available through such networks, and the role of technologies and market offerings, following the recent suggestions of Mason and Spring (2011). This study introduces the concept of coopetition-based business models, which includes simultaneously collaborative and competitive actors within the same context, and has specific implications for value creation and capture.

On a more detailed level, we first proposed that, by increasing the size of the competitor's markets or creating completely new markets for them as part of the firm's business model, potential is provided for the firm to capture a portion of the increased customer value. This result resonates with the recent findings suggesting that the presence of a variety of competing offerings is seen as valuable from the customer perspective and can eventually be helpful to the focal firm as well (Wang \& Xie, 2011). Furthermore, the results support the notions that compatibility, interoperability, and joint utilization of similar, supplementary resources are major value creation drivers in coopetition (supporting the notions forwarded by Gnyawali \& Park, 2009; Mione, 2009; Ritala \& Hurmelinna-Laukkanen, 2009).

Secondly, we proposed that the firm can capture resource efficiency benefits by sharing its resources with competitors through a coopetition-based business model. This effect is built through two mechanisms: the increased application of resources and better leveraging of differentiated resources of competitors individually. As for application, this means using fewer resources to realize a certain amount of value in a distinct part of the value chain due to the sharing of resources between competitors in the attempt to build economies of scale (see, e.g., Dussauge et al., 2000). As for synergy, the efficiency comes from utilizing certain resources in one part of the value chain to build leverage in other parts, leading to increased individual value capture for each firm (e.g., joint utilization of a sales platform to increase the impact of differentiated offerings).

Thirdly, we proposed that involving competitors inside the firm's business model provides the potential for an improved resource and competitive positioning against other business models in the industry, which increases the firm's value capture potential. This suggestion is in line with the discussion about competitive dynamics moving towards competition between networks and ecosystems, rather than residing solely between individual firms (e.g., Gueguen, 2009; Möller \& Rajala, 2007; Vanhaverbeke \& Noordehaven, 2001). This adds another dimension to the business model design discussion, where the linkages between the firm and its stakeholders - including competitors - are a key focus (e.g. Zott \& Amit, 2007). When building on the logic of coopetition, a competitive business model involves both horizontal competitiveness in terms of an improved variety of competitive offerings bringing customer value and vertical competitiveness in terms of a strong network of suppliers and delivery channels. Recent discussion on business ecosystems and value networks builds on this notion, suggesting that both horizontal and vertical elements are needed to grow a competitive, overall system that creates superior customer value (Gueguen, 2009; Möller \& Rajala, 2007).

\subsection{Managerial implications}

For business practitioners, our study proposes several interesting implications. First, in general, collaborating with a competitor is considered to be impractical and counterintuitive for many business managers and practitioners. The in-depth longitudinal Amazon.com case shows that coopetition, although a risky undertaking, can lead to the survival, growth, and evolution of a company over time. By giving thought to the implications of the coopetitive-based business models of Amazon.com, organizational decision makers and participants can have reflective conversations about the possibility of replicating Amazon.com's strategies in their own business models. The case study can also encourage managers to embark on a journey to gain insights into the network 
and organizational structures that can accommodate the complexities inherent in coopetition as a multifaceted inter-organizational relationship. In a broader view, the take home message for managers and practitioners is that judgment is a prime ingredient in strategic decisions that cannot be made solely by means of analytics-driven or mathbased approaches. In some cases, the judgments formed by the managers, although counterintuitive, can bring about extraordinary results. Thus, our study can serve as a basis for formulating normative recommendations on two important aspects of coopetition: the underlying incentives (i.e., the why) and the requisite structure (i.e., the how) of coopetitive relationships, strategies, and business-models.

Second, our study shows that the fact that the competitors are operating in the same domain can lead to forming business models with new types of mechanisms for value creation and capture. By collaborating with its competitors, a company can build new capabilities and gain better leverage on its current ones, as well as boosting its brand and technologies (such as in the case of Amazon Services). This mechanism also works vice versa, in that the company can leverage its competitors' resources through coopetition-based business models and increase the overall value for its own customers.

Finally, the case shows that coopetition can have long-term structural effects on whole industries. Managers should thus closely watch the types of coopetition-based business models being formed and examine how their companies can stay aboard and ahead of industry evolution in this regard.

\subsection{Limitations and further research directions}

Our results suffer from the typical limitations of a case study in that they are bound to a particular industry and company. We are also limited by our reliance on using mainly secondary data. Being an internet-driven company, Amazon.com has been able to exploit the many advantages of coopetition that are not necessarily available for companies in other industries (e.g., network externalities, platform sharing). We believe, however, that the propositions presented here are sufficiently universal and that future research could further examine their applicability, as well as the interesting boundary conditions. Particularly useful would be studies focusing on different industries and types of business models other than those presented here. For example, future studies could compare coopetition-based business models in different industries to see how the different drivers (e.g., the ones mentioned in this study) of coopetition are utilized in practice. Other research could also analyze the specifics of business model evolution for particular companies and industries to see how coopetition has affected them over time. In particular, studies using primary data and the longitudinal case approach could discern whether business models are deliberately planned from the coopetition perspective or if the phenomenon is emergent. Finally, quantitative studies could focus on the effectiveness of including coopetition as part of the firm's overall business model and examine potential performance implications. In this regard, the propositions formulated in this study could act as a starting point for forming empirically testable hypotheses.

\section{References}

Amazon.com Investor Relations (2011). Annual reports and proxies (Retrieved June 26, 2011, from http://phx.corporate-ir.net/phoenix.zhtml?c=97664\&p=irol-reportsannual)

Amazon.com Investor Relations (2013). Company facts. (Retrieved January 20, 2013, from http://phx.corporate-ir.net/phoenix.zhtml?c=176060\&p=irol-factSheet)

Ambrosini, V., Bowman, C., \& Collier, N. (2010). Using teaching case studies for management research. Strategic Organization, 8, 206-229.

Amit, C., \& Zott, R. (2001). Value creation in e-business. Strategic Management Journal, 22, 493-520.

Amit, C., \& Zott, R. (2010). Business model design: An activity system perspective. Long Range Planning, 43, 216-226.

Anand, B., Olson, P., \& Tripsas, M. (2009). eReading: Amazon's Kindle. Case study 9-709-486. Boston, MA: Harvard Business School.

Andersen, E., \& Fjelstad, Ø. D. (2003). Understanding interfirm relations in mediation industries with special reference to the Nordic mobile communication industry. Industrial Marketing Management, 32, 397-408.
Applegate, L. (2002). Amazon.com: 1994 - 2000. Case study 9-801-194. Boston, MA: Harvard Business School.

Applegate, L. (2008). Amazon. com: The Brink of Bankruptcy. Case study 9-809-014. Boston, MA: Harvard Business School.

Baxter, P., \& Jack, S. (2008). Qualitative case study methodology: Study design and implementation for novice researchers. The Qualitative Report, 13, 544-559.

Bengtsson, M., \& Kock, S. (2000). "Coopetition" in business networks - to cooperate and compete simultaneously. Industrial Marketing Management, 29, 411-426.

Brandenburger, A.M., \& Nalebuff, B. J. (1996). Co-opetition. New York: Currency/ Doubleday.

Brandt, R. L. (2011). One click: Jeff Bezos and the rise of Amazon.com. London: Portfolio.

Chen, M. -J. (1996). Competitor analysis and interfirm rivalry: toward a theoretical integration. Academy of Management Review, 21, 100-134.

Chesbrough, H., \& Rosenbloom, R. S. (2002). The role of the business model in capturing value from innovation: evidence from Xerox Corporation's technology spin-off companies. Industrial and Corporate Change, 11, 529-555.

Chiles, C. R., \& Dau, M. T. (2005). An analysis of current supply chain best practices in the retail industry with case studies of Wal-Mart and Amazon.com. Massachusetts Institute of Technology.

Choi, P., Garcia, R., \& Friedrich, C. (2010). The drivers for collective horizontal coopetition: A case study of screwcap initiatives in the international wine industry. International Journal of Strategic Business Alliances, 1, 271-290.

Christ, J., \& Slowak, A. (2009). Why Blu-Ray vs. HD-DVD is not VHS vs. Betamax: the co-evolution of standard-setting consortia. FZID Discussion Papers, 05/2009.

Clarke-Hill, C., Li, H., \& Davies, B. (2003). The paradox of co-operation and competition in strategic alliances: Towards a multi-paradigm approach. Management Research News, $26,1-20$.

Collura, M., \& Applegate, L. M. (2000). Amazon.com: exploiting the value of digital business infrastructure. Case study 9-800-330. Boston, MA: Harvard Business School.

Creswell, J. W., \& Miller, D. L. (2000). Determining validity in qualitative inquiry. Theory Into Practice, 39, 124-130.

Das, T. K., \& Teng, B. -S. (2000). A resource-based theory of strategic alliances. Journal of Management, 26, 31-61.

Dignan, L. (2012). Netflix and Amazon: Quite the co-opetition case study. ZDNet. (Retrieved January 28, 2013, from http://www.zdnet.com/netflix-and-amazon-quite-the-coopetition-case-study-7000008120/)

Duntemann, J., \& Pronk, R. (1994). Inside the powerPC revolution: The inside story behind the chips, software, and machines that are changing the computer industry. Albany NY: Coriolis Group Books.

Dussauge, P., Garrette, B., \& Mitchell, W. (2000). Learning from competing partners: Outcomes and durations of scale and link alliances in Europe, North America and Asia. Strategic Management Journal, 21, 99-126.

Dyer, J. H., \& Singh, H. (1998). The relational view: Cooperative strategy and sources of interorganizational competitive advantage. Academy of Management Review, 23, 660-679.

Dyer, J. H., Singh, H., \& Kale, P. (2008). Splitting the pie: Rent distribution in alliances and networks. Managerial and Decision Economics, 29, 137-148.

Eisenhardt, K. (1989). Building theories from case study research. Academy of Management Review, 14, 532-550.

Frey, C., \& Cook, J. (2004). How Amazon.com survived, thrived and turned to profit. Seattle Post-Intelligencer (January 28).

Garrette, B., Castañer, X., \& Dussauge, P. (2009). Horizontal alliances as an alternative to autonomous production: Product expansion mode choice in the worldwide aircraft industry 1945-2000. Strategic Management Journal, 30, 885-894.

Gnyawali, D. R., He, J., \& Madhavan, R. (2006). Impact of co-opetition on firm competitive behavior: An empirical investigation. Journal of Management, 32, 507-530.

Gnyawali, D. R., \& Park, B. -J. (2009). Co-opetition and technological innovation in small and medium-sized enterprises: A multilevel conceptual model. Journal of Small Business Management, 47, 308-330.

Gnyawali, D. R., \& Park, B. -J. (2011). Co-opetition between giants: Collaboration with competitors for technological innovation. Research Policy, 40, 650-663.

Gomes-Casseres, B. (1994). Group versus group: How alliance networks compete. Harvard Business Review, 72, 62-71.

Gueguen, G. (2009). Coopetition and business ecosystems in the information technology sector: The example of intelligent mobile terminals. International Journal of Entrepreneurship and Small Business, 8, 135-153.

Gwynne, P. (2009). Automakers hope coopetition will map route to future sales. Research Technology Management, 52, 2-4.

Hamel, G. (1991). Competition for competence and inter-partner learning within international strategic aliances. Strategic Management Journal, 12, 83-103 (Summer specia issue).

Halinen, A., \& Törnroos, J.-Å. (2005). Using case methods in the study of contemporary business networks. Journal of Business Research, 58, 1285-1297.

Ignatius, A. (2013). Jeff Bezos on leading for the long-term at Amazon, Harvard Business Review IdeaCast. (from: http://blogs.hbr.org/ideacast/2013/01/jeff-bezos-on-leadingfor-the.html)

Mariani, M. (2007). Coopetition as an emergent strategy. International Studies of Management E' Organization, 37, 97-126.

Möller, K., \& Rajala, R. (2007). Rise of strategic nets - New modes of value creation. Industrial Marketing Management, 36, 895-908.

Kalpanik, S., \& Zheng, C. (2011). Inside the giant machine - An Amazon.com story (2nd ed.) Los Angeles, CA: Center of Artificial Imagination, Inc. Kindle edition.

Kalpanik, S. (2011). Seattle adventures - Seattle memoirs inspired by my stint at Amazon.com. Seattle: Createspace.

Katz, M. L., \& Shapiro, C. (1985). Network externalities, competition and compatibility. American Economic Review, 41, 8-32. 
Kirby, J., \& Stewart, T. (2007). How Amazon's CEO leads strategic change in a culture obsessed with today's customer. Harvard Business Review, 85(10), 75-82.

Kock, S., Nisuls, J., \& Söderqvist, A. (2010). Co-opetition: A source of international opportunities in Finnish SMEs. Competitiveness Review, 20, 111-125.

Lado, A. A., Boyd, N. G., \& Hanlon, S.C. (1997). Competition, cooperation, and the search for economic rents: A syncretic model. Academy of Management Review, 22, 110-141.

Lane, P. J., \& Lubatkin, M. (1998). Relative absorptive capacity and interorganizational learning. Strategic Management Journal, 19, 461-477.

Lavie, D. (2006). The competitive advantage of interconnected firms: an extension of the resource-based view. Academy of Management Review, 31, 638-658.

Levy, S. (2011). Jeff Bezos owns the web in more ways you think. Wired, December 2011. (Retrieved December 1, 2012, from http://www.wired.com/magazine/2011/11/ ff_bezos/all/1)

Mason, K., \& Spring, M. (2011). The sites and practices of business models. Industrial Marketing Management, 40, 1032-1041.

Mione, A. (2009). When entrepreneurship requires coopetition: The need for standards in the creation of a market. International Journal of Entrepreneurship and Small Business, 8, 92-109.

Oum, T. H., Park, J. -H., Kim, K., \& Yu, C. (2004). The effect of horizontal alliances on firm productivity and profitability: Evidence from the global airline industry. Journal of Business Research, 57, 844-853.

Oxley, J. E., Sampson, R. C., \& Silverman, B. S. (2009). Arms race of détente? How interfirm alliance announcements change the stock market valuation of rivals. Management Science, 55, 1321-1337.

Padula, G., \& Dagnino, G. B. (2007). Untangling the rise of coopetition. The intrusion of competition in a cooperative game structure. International Studies of Management $\mathcal{E}$ Organization, 37(2), 32-52.

Perry, M. L. Sengupta, S., \& Krapfel, R. (2004). Effectiveness of horizontal strategic alliances in technologically uncertain environments: Are trust and commitment enough? Journal of Business Research, 57, 951-956.

Peng, T. A., Pike, S., Yang, J. C., \& Roos, G. (2012). Is cooperation with competitors a goo idea? An example in practice. British Journal of Management, 23, 532-560.

Quintana-García, C., \& Benavides-Velasco, C. A. (2004). Cooperation, competition, and innovative capability: A panel data of European dedicated biotechnology firms. Technovation, 24, 927-938.

Ritala, P., \& Hurmelinna-Laukkanen, P. (2009). What's in it for me? Creating and appropriating value in innovation-related coopetition. Technovation, 29, 819-828.

Ritala, P., Hurmelinna-Laukkanen, P., \& Blomqvist, K. (2009). Tug of war in innovation Coopetitive service development. International Journal of Services, Technology and Management, 12, 255-272.

Ritala, P. (2009). Is coopetition different from cooperation? The impact of market rivalry on value creation in alliances. International Journal of Intellectual Property Management, 3, 39-55.
Ritala, P. (2012). Coopetition strategy - When is it successful? Empirical evidence on innovation and market performance. British Journal of Management, 23, 307-324.

Rose, C., \& Bezos, J. (2011). Video interview. (Retrieved May 16, 2011, from http://www. youtube.com/watch? $\mathrm{v}=$ fAoOIfOCevA

Roy, P., \& Yami, S. (2009). Managing strategic innovation through coopetition. International Journal of Entrepreneurship and Small Business, 8, 61-73.

Rusko, R. (2011). Exploring the concept of coopetition: A typology for the strategic moves of the Finnish forest industry. Industrial Marketing Management, 40, 311-320.

Saunders, M., Lewis, P., \& Thornhill, A. (2009). Research methods for business students (5th ed.): FT/Prentice Hall.

Segrestin, B. (2005). Partnering to explore: The Renault-Nissan alliance as a forerunner of new cooperative patterns. Research Policy, 34, 657-672.

Shin, J., \& Park, Y. (2009). On the creation and evaluation of e-business model variants: The case of auction. Industrial Marketing Management, 38, 324-337.

Sharma, A. (2002). Trends in Internet-based business-to-business marketing. Industrial Marketing Management, 31, 77-84.

Spector, R. (2002). Amazon.com: Get big fast. New York: Collins Business.

Spiegel, M. (2005). Coopetition in the telecommunications industry. In M.A. Crew, \& M. Spiegel (Eds.), Obtaining the Best from Regulation and Competition. Boston, MA: Kluwer Academic.

Teece, D. (2010). Business models, business strategy and innovation. Long Range Planning, 43, 172-194.

The Economist (2012). Taking the long view. The Economist. (Retrieved December 10, 2012, from: http://www.economist.com/node/21548487)

Tidström, A. (2009). Causes of conflict in intercompetitor cooperation. Journal of Business E' Industrial Marketing, 24, 506-518.

Timmers, P. (1998). Business models for electronic markets. Electronic Markets, 8(2), 3-8.

van Heck, E., \& Vervest, P. (2007). Smart business networks: How the network wins. Communications of the ACM, 50, 29-37.

Vanhaverbeke, W., \& Noordehaven, N. G. (2001). Competition between alliance blocks: The case of the RISC microprocessor technology. Organization Studies, $22,1-30$

Walley, K. (2007). Coopetition. An introduction to the subject and an agenda for research. International Studies of Management and Organization, 37, 11-31.

Wang $\mathrm{Q}$, \& Xie, J. (2011). Will consumers be willing to pay more when your competitors adopt your technology? The impacts of the supporting-firm base in markets with network effects. Journal of Marketing, 75, 1-17.

Yin, R. (2003). Case study research: Design and methods (3rd ed.)Thousand Oaks, CA: Sage.

Zott, C., \& Amit, R. (2007). Business model design and the performance of entrepreneurial firms. Organization Science, 18, 181-199.

Zott, C., \& Amit, R. (2008). The fit between product market strategy and business model: Implications for firm performance. Strategic Management Journal, 29, $1-26$. 